Indexed by

\title{
Scopus
}

\section{PROJECT FINANCING THROUGH PUBLIC-PRIVATE PARTNERSHIPS IN COLOMBIA: A LOOK INSIDE OF 4G HIGHWAY CONCESSIONS}

Crossref

$\begin{aligned} \mathrm{ROAD}= & \begin{array}{l}\text { Institución Universitaria Es- } \\ \text { umer, Facultad de Estudios } \\ \text { Empresariales, Medellín, } \\ \text { Colombia } \\ \text { Institución Universitaria Pas- } \\ \text { cual Bravo, Facultad de Inge- } \\ \text { niería, Medellín, Colombia }\end{array}\end{aligned}$

niería, Medellín, Colombia

Juan David Gonzalez-Ruiz

Universidad Nacional de

Colombia, Facultad de Ciencias Humanas y Económicas, Departamento de Economía, Medellín, Colombia

\section{Carolina Vargas-Vargas}

Institución Universitaria Esumer, Facultad de Estudios Empresariales, Medellín, Colombia

\author{
Julián Patiño-Murillo \\ Institución Universitaria Pas- \\ cual Bravo, Facultad de Inge- \\ niería, Medellín, Colombia
}

\author{
Miguel A. Becerra \\ Institución Universitaria Pas- \\ cual Bravo, Facultad de Inge- \\ niería, Medellín, Colombia
}

Key words: funding process, highway infrastructure, project finance, public-private partnerships doi:10.5937/jaes0-29044

\section{Cite article:}

Duque-Grisales, E., Vargas-Vargas, C., Patino-Murillo, J., Gonzalez-Ruiz, J. D., Becerra, M.A. (2021) PROJECT FINANCING THROUGH PUBLIC-PRIVATE PARTNERSHIPS IN COLOMBIA: A LOOK INSIDE OF 4G HIGHWAY CONCESSIONS, Journal of Applied Engineering Science, 19(3), 757-767, DOI:10.5937/jaes0-29044

Online aceess of full paper is available at: www.engineeringscience.rs/browse-issues 


\title{
PROJECT FINANCING THROUGH PUBLIC-PRIVATE PARTNERSHIPS IN COLOMBIA: A LOOK INSIDE OF 4G HIGHWAY CONCESSIONS
}

\author{
Eduardo Duque-Grisales ${ }^{1,2 *}$, Carolina Vargas-Vargas' ${ }^{1}$, Julián Patiño-Murillo², Juan David Gonzalez-Ruiz ${ }^{3}$, \\ Miguel A. Becerra ${ }^{2}$ \\ 'Institución Universitaria Esumer, Facultad de Estudios Empresariales, Medellín, Colombia \\ 2Institución Universitaria Pascual Bravo, Facultad de Ingeniería, Medellín, Colombia \\ ${ }^{3}$ Universidad Nacional de Colombia, Facultad de Ciencias Humanas y Económicas, Departamento de \\ Economía, Medellín, Colombia
}

This article analyzes the benefits of the financing scheme through Public-Private Partnerships for the Fourth Generation Highway Concessions Program in Colombia. In this program, the Government of Colombia establishes a concession for 25 years on highways and guarantees income through the Collection Difference Compensation Mechanism in years 8,13 , and 18. A case study is presented on the 4G highway "Autopista al Mar 2" to identify the commercial risks that may be caused by the difference in the collection between the concessionaire and the Colombian government. For this, three traffic scenarios are proposed to evaluate their impact on obtaining the Present Value from Toll Revenue - PVTR. Results show that this highway is financially viable for the base scenario through the project's finance scheme, and the commercial risk is not increased by the collection differences in any of the years 8, 13, or 18. The analysis foresees an additional income for the concessionaire of USD 123.19 million. Similar results were obtained in the optimistic scenario, with an additional collection of USD 655.90 million, which generates additional revenue to the concessionaire for operation and maintenance costs. However, if there is a $30 \%$ decrease in the estimated traffic in the baseline scenario, the PVTR will not be reached within 25 years of the concession, and the risk of Collection Difference is activated in the year 18, with an amount of USD 1.11 million; the Colombian State must provide this sum to the concessionaire. Finally, these results help create a roadmap on critical issues that require adjustments or improvements in the financing process to drive the effective development of $4 G$ concessions.

Key words: funding process, highway infrastructure, project finance, public-private partnerships

\section{INTRODUCTION}

The importance of transport infrastructure systems is supported by the benefits they bring to improving quality and coverage levels. This is one of the main challenges Colombia faces, especially in small and medium-sized cities, due to the interest in poverty reduction. It is impossible to fight poverty without adequate connectivity infrastructure, nor is it possible to improve people's quality of life and boost Colombian economic development without generating a transportation infrastructure that provides greater coverage and quality of services derived from it [1]. Therefore, it is necessary to increase the current levels of investment, promote improvements in transport infrastructure, and prioritize financing mechanisms [2], [3]. Colombia is a developing country located in South America, close to the equator. It is a country that mainly exports commodities and services and has an approximate population of 50 million inhabitants. In Colombia, investment in infrastructure from years 2002 to 2018 averaged $3.2 \%$ of its GDP (Gross Domestic Product) [4]. As suggested by the Andean Development Corporation (CAF), it is necessary to reach average investment levels of $5 \%$, but budgetary limitations and the low debt capacity of the public sector restrict the investment to a maximum of $2.5 \%$ [5], [6]; this percentage of resources is insufficient to face this gap. In this sense, there is a strong need for exploring suitable financing alternatives to change this reality. Therefore, the analysis and characterization of the financing strategies to develop infrastructure in the transport sector could improve such processes and effectively attract the private sector's engagement. This paper aims at filling this gap and present Public-Private Partnerships (PPP) as a strategy for linking the private sector in financing large road infrastructure projects in Colombia in order to improve production efficiencies [7], [8]; it also seeks to streamline the infrastructure development process, and the risk transference to the private sector, among other benefits.

As a tool to increase competitiveness, between 2014 and 2015, the National Government of Colombia, through the National Infrastructure Agency (ANI, by the acronym in Spanish), granted the fourth generation of highway concessions (4G concessions) through PPP; it seeks to improve the quality of the country's roads. With the PPP contractual scheme, these road concessions mean that the private sector oversees the design, construction, operation, and maintenance of these roads, as well as their financing. In this way, this seeks to guarantee that they can be financed through a structure called Project 
Finance (PF), in which each concession's income flows must be sufficient to repay the debt and, occasionally, the equity of each of them. Lately, Project Finance is becoming the preferred method to finance infrastructure works and large-scale projects worldwide [9]-[12].

This paper exposes the use of the Project Finance methodology and its application in the $4 G$ concessions. The financing strategies developed under PPP must be analyzed and characterized to enhance the identification process of linking, developing, and financing these projects by the private sector. As an application case, the 4G concessions "Autopista al Mar 2" and its financing process are reviewed to identify its financial viability and the risks to which the project may be exposed. The main contribution of this work is the analysis and characterization of the financing strategies of transportation infrastructure projects through PPP.

\section{THEORETICAL FRAMEWORK}

\section{Public private partnerships in Colombia}

Participation from both the public and private sectors is vital to meet infrastructure investment needs [13], [14]. Consequently, governments have been using Public-Private Partnerships as a strategy to involve the private sector in financing large infrastructure projects [15]-[19]. Colombia has not been oblivious to implementing this private participation scheme, and the public sector has welcomed the strategy because the State does not have the necessary resources to finance all the basic infrastructure works for the country [4], [20]. This type of financing has been promoted mainly as the solution to the infrastructure gap that the country experiences in order to improve production efficiencies [8], [18], [21]; as well as streamlining the process of infrastructure development, transferring risks to the private sector and directing public funds towards social needs where the private sector would not invest [22], [23]. For this purpose, both the Ministry of Transportation and the National Planning Department issued Law 1508 in 2012, under the National Congress's approval. With Law 1508, Colombia adopted the PPP scheme to increase the private sector's participation, making the investment in large-scale infrastructure projects more attractive. This 2012 norm was regulated by Decree 1467 that addressed the terms and conditions for the associate selection, signature and execution of the contract, procedures, and criteria for the selection of public and private initiatives, contributions from public entities, and the conditions for the compliance with availability, service levels and quality standards that PPP must meet. This Decree establishes:

"Public-Private Associations are an instrument for linking private capital. They materialize in a contract between a state entity and a natural or legal person under the private law, for the provision of public goods and their related services, which involves withholding and transfer, risks between the parties and payment mechanisms, related to the availability and level of service of the infrastructure and/or service [26, art. 1, p. 1]".
One of the most significant changes introduced by 2012 Law 1508, through Article 5, later modified by article 37 of 2015 Law 1753, was to condition the remuneration from State resources to contractors, in terms of availability, at the service level and the quality standards set in each contract. In the $4 \mathrm{G}$ highway case, the private investor must finance the infrastructure's construction until it delivers the units in operation (as many as the project is divided into). This change seeks to encourage the contractor to complete the works in less time to obtain the right to receive the remuneration quickly. Besides, the Law conditioned the contractors' remuneration to the availability of the infrastructure and the compliance with service levels and quality standards, and the use of suitable quality materials. The latter implies that the contractors should invest fewer resources during operation and maintenance tasks, the so-called Operating Expenditures - OPEX. To manage public and private resources in the projects, the contractor must constitute autonomous equity conformed by all the assets and liabilities associated with each project. Also, the maximum term for this type of project was set at 30 years.

In the year 2011, Colombia's National Planning Department -DNP stated that the development of infrastructure projects executed with capital from the private sector should be strengthened with PPP contracts; this is due to these models' characteristics, which reduce both the legal and financial risks of traditional financing mechanisms. Thus, PPP schemes ensure adequate risk allocation and allow financing through securities' issuance with credit content or participation in the capital market. For such cases, the Project Finance (PF) technique is closely related to the PPP concept. Infrastructure projects in Colombia are carried out in the phases described in Figure 1.

\section{Project finance}

The PF structure has been used worldwide to finance large-scale infrastructure projects for construction, operation, and maintenance under the PPP scheme [22], [25], [26]. According to Albújar [27], Project Finance techniques are required to properly structure a PPP, where the private sector must finance $100 \%$ of the investment to design, build and operate the infrastructure. The PF is a structured financing mechanism that depends on the cash flows generated by the project during its operation; it also depends on the risks assumed by the project's shareholders or sponsors, in such a way that the debt service payment guarantee often is the same project's assets. These are developed in an independent vehicle (Special Purpose Vehicle - SPV) that is outside the balance sheet of the shareholders or sponsors that participate in the project [22], [28], [29]. In this way, in $P F$, it is understood that the project has expected income streams that make it possible to repay the debt without having to compromise the investors' assets as collateral guarantee for the funders. Figure 2 shows the basic structure of PF.

Istraživanja i projektovanja za privredu ISSN 1451-4117 Journal of Applied Engineering Science Vol. 19, No. 3, 2021 


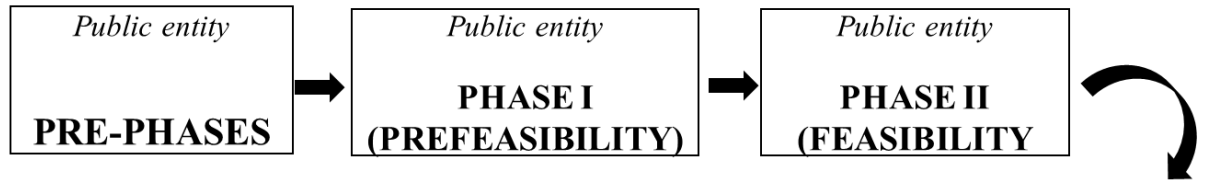

Conceptual Estimation
1. Key risk
2. Needs
3. Legal framework

\section{Cost Estimation}

1. Preliminary logistics

2. Financing alternatives

\section{Structuring}

1. Master plan

2. Budgets

3. Logistics strategy

4. Financial models

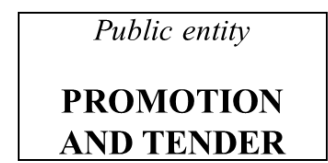

AND TENDER

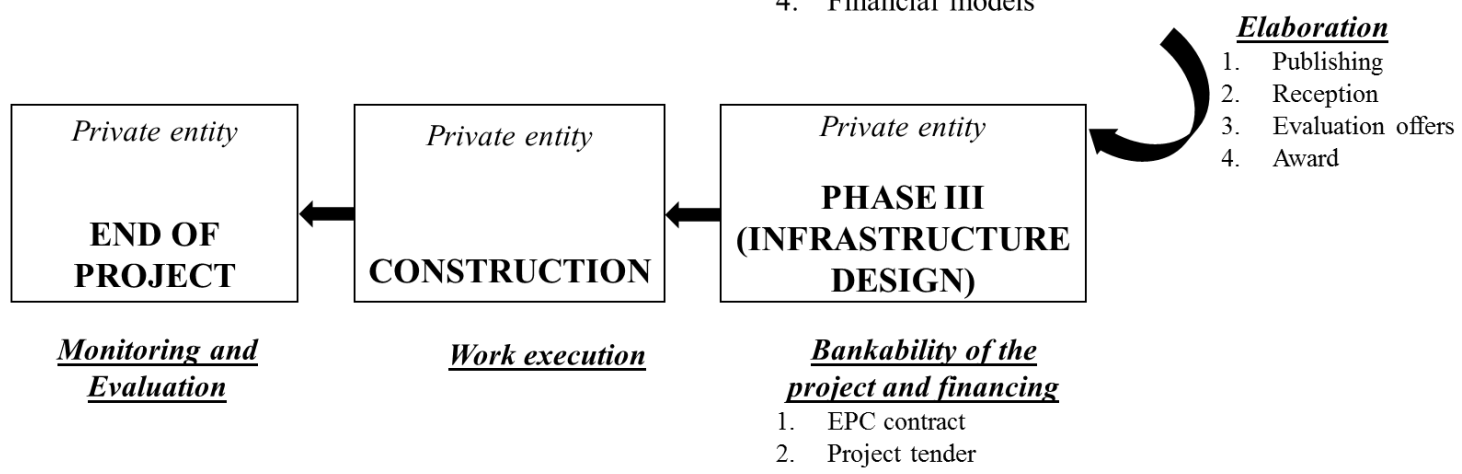

Figure 1: Phases of an infrastructure project in Colombia

An important reason to use the PF is that investments for an infrastructure project, specifically road concessions, require large financing levels in the short term [30]. Usually, in the construction stage, works are carried out with the highest levels of investment; and it is in the long term (in the operational stage) where the positive cash flows are generated, with the money collected from tolls of the roads in concession. Then, the return on investment will be obtained. In this sense, high financial leverage improves the revenue for the investor [31].

Before carrying out a project under the PF scheme, a financial study must ensure that the cash flow generated can cover the expenses caused by the credit. On the other hand, certain agreements must provide the necessary funding for project start-up and operation. This also ensures capital availability to cover expenses and obligations at the start of operations and the project's possible difficulties [22]. Additionally, the PF has special characteristics that oblige the State and the private sec- tor to share the risks to make the project viable. Usually, the State seeks to transfer greater risk to the private sector, although the State can assume a more significant percentage depending on the project [32].

The financial structure of Project Finance seeks to maximize the project's profitability for investors. An efficient project requires adequate cash flow planning under different scenarios and risks to generate enough funds for paying obligations and returning the invested capital. In general, the financial structure must be under the promoters' objectives and the financial entities participating in the project. After defining each of the project's financial structure determinants, the best combination of debt and equity is identified. Everything will depend on two points of view: in the first place, the promoters will seek to contribute the lowest percentage of capital to obtain the highest possible return. Second, the allowed creditors would require that the capital contribution be as high as possible because the amount of contributed capital

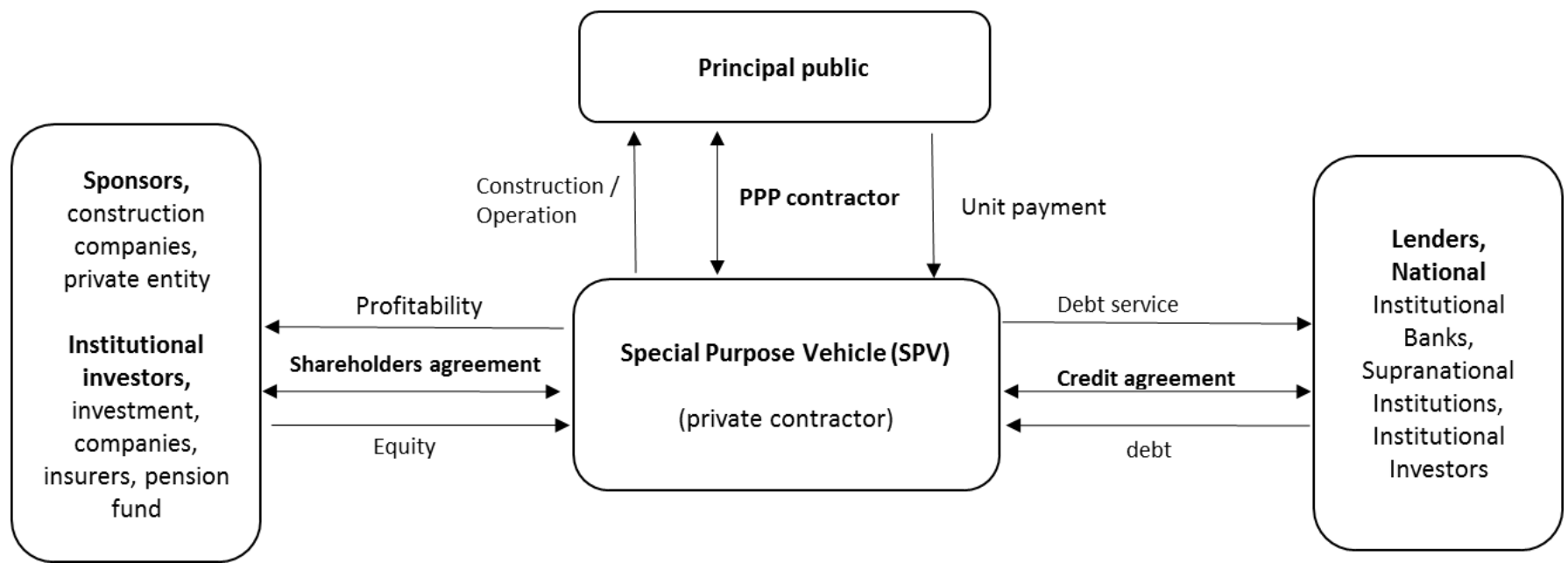

Figure 2: Project finance structure 
indicates the commitment of the promoters in the project, and it also operates as a kind of guarantee regarding the return of debt. The main guarantee that lenders have is the project's ability to generate cash flows. Therefore, creditors must ensure the loan's payment (principal and interest) in the established period by the debt's term.

\section{Methodology for financing infrastructure projects through PPP: A Case Study of 4G highways}

The National Government of Colombia structured 4G concessions according to the PPP scheme to correct errors in previous projects and to improve the country's capacity of road infrastructure and achieve adequate regional connectivity and strengthen the country's competitiveness. This program was named because the government classified the roads as first, second, third, and fourth generations when proposing the road infrastructure development program. For this generation of concessions, ANI hired a group of integral structuring companies to structure public initiative PPP; they designed the standard contract (general part of the 4G Concession Contract) applicable to all contracts of this generation and which regulates most of the common aspects of the projects.

In the construction stage, 4G concessions have a duration of two (2) to five (5) years and a concession period of twenty-five (25) years. An aspect to highlight is that $4 \mathrm{G}$ projects are led towards reducing traveling time and operating costs in the transport of goods. At the same time, they seek to boost tourism development. It is estimated that they will bring benefits to seventy-nine (79) municipalities located in thirteen (13) provinces, with a target population of 5,254,631 inhabitants (DNP, 2014). The program expects to create a multiplier effect on the economy, increasing GDP by $1.5 \%$ during construction. For the long term, it will produce a potential growth in GDP, going from $4.6 \%$ to $5.3 \%$, generating more than 215,000 direct jobs and 144,000 indirect jobs during the construction stage; this would reduce the unemployment rate in the long term by $1 \%$.

According to Colombia's Ministry of Transport, the fourth generation of concessions is the country's most extensive highway infrastructure program so far; it will develop capabilities to be more competitive and meet international trade challenges. The program is based on Law 1508 on Public-Private Partnerships and seeks to solve the country's infrastructure deficit by investing around USD 23,500 million in 2012 constant terms, in investments in capital goods which are necessary for works' development and execution - (Capital Expenditure -CAPEX-). These investments will be carried out in eight years from its hiring, and then, the operation and maintenance of the roads would begin for periods between 25 and 30 years. These CAPEX investments, plus the necessary resources for the roads' operation and maintenance, will be remunerated to the concessionaires through money from tolls and public resources' contribution from the Nation's General Budget. For these concessions, roughly $65 \%$ of the required resources will be used for CAPEX and the remaining $35 \%$ for OPEX.

The 4G highways Program has 20 projects granted through PPP contracts with an investment amount of approximately USD 14,900 million (projects 1-20) and 11 private initiatives for about USD 6,700 million. The size of this financing challenge faced by the country implies a transformation of the current infrastructure financing model, moving from a scenario where the distribution of risk was more concentrated on the government, with low capital requirements to concessionaires and the financing basically from corporate loans to a maximum of 10 years. The new scenario is a non-traditional model such as Project Finance (which allows an appropriate allocation of risk between the public and private sectors, whose main characteristic is implementing international standards and best practices). Specifically, 4G concessions operate under the PPP scheme and present a novelty in risk distribution since most of these risks are transferred to the private sector, the central development axis of public policy in the Colombian transport infrastructure area.

This new payment scheme circumscribed by 2012 Law 1508 proposes the availability payment, which means that the State's return on investment is manifested to the concessionaire once the infrastructure is available under service and quality standards per Decree 1467 from 2012. However, for partially executed projects due to inconveniences in land issues or environmental licenses, the payment mechanism should be negotiated. The latter case results because the availability payment figure would not be fulfilled, and therefore, the concept of available infrastructure would not exist. Another novelty lies in the contingent liability management system that arises from the guarantees offered to toll road concessions. This system includes estimating the fiscal impact of the Nation's Budget provided by ANI and the guarantees before they are granted and setting aside funds to cover the estimated payments of the guarantees through the contingent liabilities fund administered by Fiduprevisora (Law 448 from 1998, Law 819 from 2003 and Law 1437 from 2011).

Additionally, remuneration is defined as the economic consideration to which the concessionaire is entitled to execute a contract. Remuneration calculation involves each functional unit of the project (from now on, FU). A FU is each of the project divisions according to the special part; they correspond to engineering structures and essential facilities that can function and operate individually so that it is possible to provide the service in each of them with functional independence. Remuneration starts from the subscription of the respective certificate of termination of each FU, tying the payment to the FU delivery by the concessionaire and fulfilling the compliance index required for each FU (derived from the weighting of different indicators). The remuneration will be understood as accepted when the resources corresponding to it (and those to special compensation, if applicable) are transferred between the corresponding autonomous 
equity subaccounts within the established terms. It is essential to differentiate the remuneration from the contract's value. The former represents the economic consideration in favor of the concessionaire. The latter is an estimated amount of investment indicated in the special part of each contract that serves as the amount to calculate the maximum value of additions for each project, according to Article 13 of Law 1508 from 2012.

The general contract foresees that the concessionaires must constitute autonomous equity to better control the destination and the specific use of the projects' resources. This equity will be the project's accounting center, involving all the economic aspects, including each project's income and expenses. All assets and liabilities must be channeled through this autonomous equity, and all project resources must be managed. Thus, according to the contract, the autonomous equity must be divided into two main accounts: the project account and ANI's account.

By the general contract, the sources for the concessionaire's remuneration are I) the contributions from $\mathrm{ANI}$, II) the money collected from tolls, and III) the income from commercial exploitation, each of them understood as follows:

- ANI contributions correspond to the amounts requested by each concessionaire as annual contributions from $\mathrm{ANI}$ to the autonomous equity; these will be expressed in constant money for the indicated year in each project's special part and must be contributed by the State entity in the terms and amounts established by the special part of each contract.

- The money collected from tolls corresponds to the amount obtained from multiplying the toll stations' effective traffic by each vehicle category's rate.

- Commercial exploitation income is the gross income obtained from each project to provide additional services received directly by the concessionaire or any other person, given that the concessionaire, its partners, or the beneficial owners have a stake. $2.2 \%$ of this income must be sent to ANI's surplus subaccount and will have the intended destination for such resources. The remaining $97.8 \%$ will be sent to the commercial exploitation income subaccount and will be considered one of the remuneration payment sources.

On the other hand, it must be considered that the equity resources destined to the project must be paid to the autonomous equity by the concessionaire's partners -investors or sponsors - to comply with the minimum capital transfers defined by the contract. The contributions of equity resources must be accounted for in the autonomous equity only as one of the following items: I) share capital contributions, II) additional paid-in, in shares placement, or III) shareholders' debt to the company; in no case, it can be a dealer-backed bank debt of the partners. The repayment of these resources can only be made at the operation and maintenance stage and will be subordinated to the project's payment of all costs, expenses, and debt resources' remuneration.
The debt resources required to finance the project may be paid to the autonomous equity by the lenders through any modality, contract, or financing instrument. Among the modalities allowed to obtain these resources, there are bank loans, securities issuance in the capital market, resources from private capital funds, or combinations of the previous modalities.

The financial closure of the project must be guaranteed, considering the project's collection and financing systems. This implies the achievement of a minimum amount of debt resources for each project by the concessionaire. These minimum debt resources must be accredited within the deadlines and in the form required by the contract. It is essential to mention that, following note (f) section 3.8 of the contract's general part, obtaining financial closure by the concessionaires does not limit their obligation to obtain all the necessary resources to execute the project entirely. Therefore, if the resources obtained become insufficient, the concessionaire will be obliged to obtain the missing resources.

\section{G concessions operation scheme: a case study of "Autopista al Mar 2"}

As previously mentioned, concessions, in general terms, are governed by the provisions contained in the general part of the concession contract, except for what the special parts of each contract provide for each case. The general part establishes (among other aspects) the definitions applicable to contracts, how the remuneration will be paid, the income sources, the project's risk allocation, and the administration of the resources associated with the autonomous equity. Some of the essential characteristics of the "Autopista al Mar 2" project are exposed below, extracted from the general part of the concession contract.

\section{General description of the project}

The roads subject of the "Autopista al Mar 2" concession have an estimated total length of 245 kilometers from origin to destination. It will connect the center of the country with the Caribbean and Pacific coasts. The project is located between the municipalities of Cañasgordas and Necoclí. It is estimated to be finished by December 2021. The concession is divided into six functional units (see Table 1), and the project's concessionaire is Autopistas Urabá SA. The concessionaire is made up of China Harbor Engineering Company (30\%), SP Ingenieros SAS (20\%), Pavimentar SA (15\%), Sonacol SAS (20\%), Associated Infrastructure and Constructions Unit SAS (10\%), and Termotécnica Coindustrial (5\%). The CAPEX for the "Autopista al Mar 2" project is USD 850 million.

Figure 3 presents the "Autopista al Mar 2" concession's intervention route, which will improve the connection between the Uraba region and the rest of Colombia. 
Table 1: Functional units of the Autopista al Mar 2 project

\begin{tabular}{|c|c|c|c|c|}
\hline FU & Sector & Type of intervention & $\begin{array}{c}\text { Max. term of execution } \\
\text { (days) }\end{array}$ & $\begin{array}{c}\text { Percentage of } \\
\text { Participation }\end{array}$ \\
\hline 1 & Cañasgordas - Uramita & Improvement & 1800 & $30.83 \%$ \\
\hline 2 & Variante Fuemia & Building & 1440 & $28.26 \%$ \\
\hline 3 & Túnel de Fuemia & Building & 1440 & $6.42 \%$ \\
\hline 4 & Dabeiba - Mutatá & Improvement and Rehabilitation & 1440 & $6.87 \%$ \\
\hline 5 & Mutatá - El Tigre & Rehabilitation & 1080 & $5.04 \%$ \\
\hline 6 & El Tigre - Necoclí & Operation and maintenance & 1080 & $22.58 \%$ \\
\hline
\end{tabular}

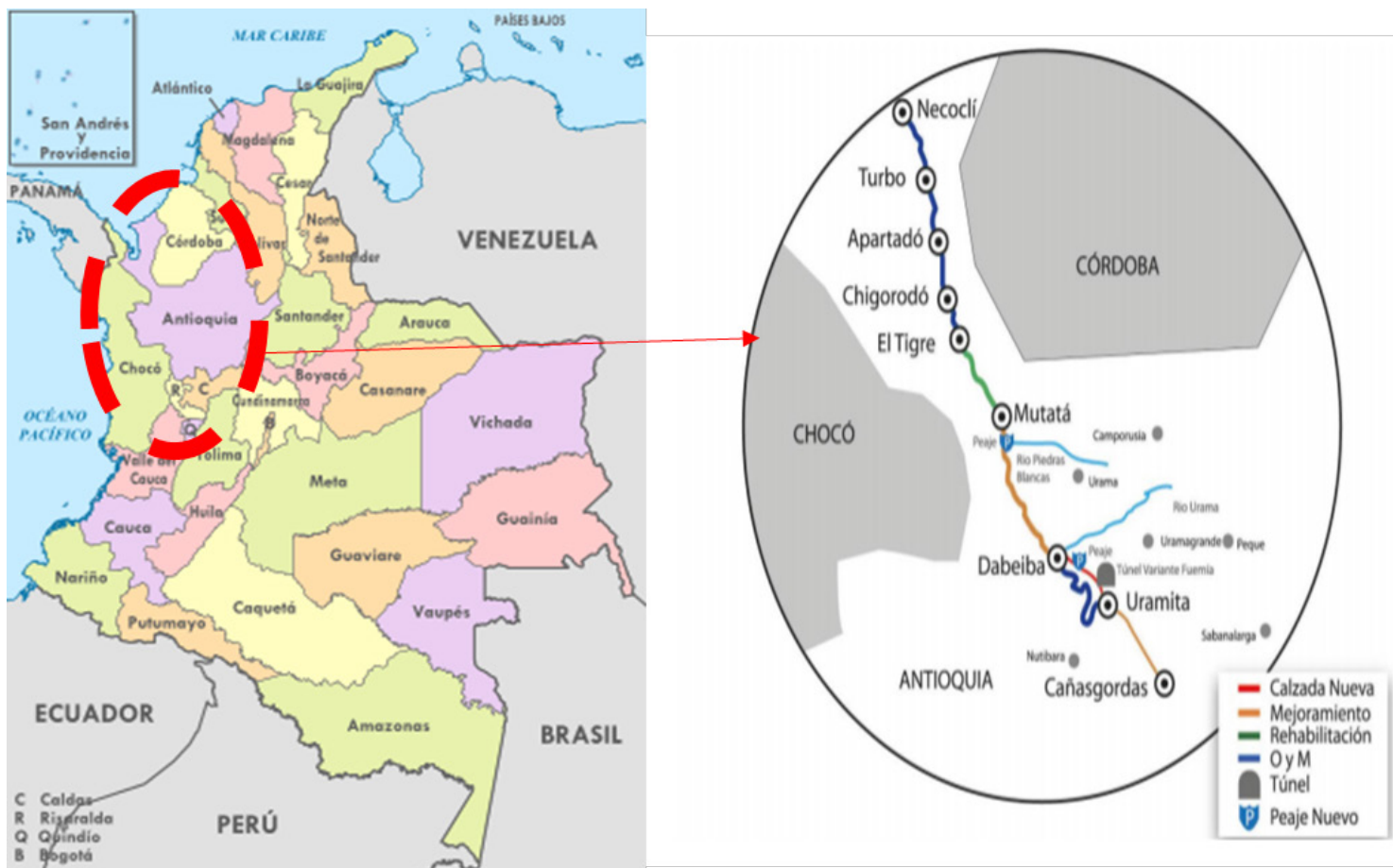

Figure 3: Intervention route for the "Autopista al Mar 2" concession

\section{Operating income}

In the "Autopista al Mar 2" concession, three income sources were established: tolls, income from commercial exploitation, and contributions from the State. Toll revenues correspond to the income received from road users, by applying the defined rate scheme for each vehicle category and by toll collection booth. Two new tolls are being built for this concession, which will come into operation with the delivery of the $6 \mathrm{FU}$ proposed in the project. In this type of project, the concept of Present Value from Toll Revenue (PVTR) is used; it is verified month by month from the moment the State transfers the money collected to the concessionaire. Commercial operating income is a source of income not considered in previous generations of concessions, and it is defined as "the gross income obtained as a consequence of the provision of additional services." $97.8 \%$ of this commercial operating income will be used as payment for the compensation to the concessionaire and, the remaining $2.2 \%$ must be deposited in the equity subaccount corresponding to the surpluses of the State entity. The State contributions will be made from the 2019 to 2035 period for a total of USD 1,750 million (in December of 2012). These values must be updated when making the compensation to the concessionaire per the previous month's CPI. In this contract, the percentage of ANI Contributions (Nation) represents $45 \%$ of the estimated income as part of the remuneration, and the toll represents the remaining $55 \%$.

It is important to note that, in $4 \mathrm{G}$ concessions, income is guaranteed through the Collection Difference Compensation Mechanism (CD) in years 8 (CD8), 13 (CD13), and 18 (CD18). I. e., if the present value of income calculated in years 8,13 , and 18 is lesser than the estimated amount of PVTR for those years, the State -through ANI- will guarantee the difference weighted by the compliance index, with the resources available in the contingency fund, transfer of surplus subaccounts or, if insufficient, through the Nation's General Budget.

The income received by the concessionaires of these projects will be conditioned to the fulfillment of the infrastructure availability and service level indicators or service provided. If not meeting the indicators, the remuneration is reduced according to the deductions per performance. 
At any time of the contract's execution, the present value at the Reference Month (December 2012) of the accumulated PVTR up to that moment (PVTRm) may be calculated, according to the following equation:

$\operatorname{PVTR}_{m}=\sum_{i=1}^{m} \frac{\text { Toll }_{i}}{(1+A D R)^{i+q}}+\sum_{j=1}^{J} \underline{\Delta}_{F=5 j+3}$

Where,

PVTR=is the Present Value from Toll Revenue until the year $n$ offered by ANI $n=8, n=13$ and $n=18$ PVTR 8, PVTR 13 o PVTR 18 correspondingly.

$\Delta \mathrm{F}=\mathrm{PVTR}_{\mathrm{F}}-\mathrm{PVTR} \mathrm{R}_{\mathrm{f}}$

$\mathrm{j}=$ number of months' counter. It starts in the contract's starting month; j's initial value varies according to the money collection difference, which is calculated as follows: (I) for CD8, j starts in month 1; (II) for CD13, j starts in month =97 and (III) for CD18, j starts in month 157.

$A D R=a c t u a l$ annual discount rate of the income expressed in effective monthly terms, set at $0,5663 \%$ for this project.

$q=$ number of months between the reference month and the starting month.

Item (b) of section 3.4 of the General Part contract indicates that, if the PVTRm value is less than the PVTR8 at the expiration of year eight (8) from the Start Date, ANI will pay the concessionaire the difference (CD8) weighted by the average Compliance Index observed up to year eight (8). The same procedure indicated above will apply to the calculation and payment of CD13 and CD18.

The calculation of the money Collection Difference will be made with the formula provided in Section 3.4 (b) (II) of the General Part, Equation 2.

$C D_{F}=\underline{\Delta}_{F}^{*} A C l_{f}^{*}\left(\frac{C P I_{f}}{C P l_{r}}\right) *(1+A D R)^{f+q}$

Where,

$C D_{F}=$ is the money collection difference expressed in Month values $\mathrm{f}$, from the starting date.

$\mathrm{F}=$ Year correspondent to the money collection difference that is calculated (CD8, CD13 o CD18, correspondingly). $\mathrm{f}=$ Number of months that passed between the starting date and the last day of the year for which the money collection difference. For CD8, $f=96$; for $C D 13, f=156$ and for CD18, $f=216$.

$\mathrm{ACl}=$ Average Compliance Index

$\mathrm{CPI}=$ Consumer Price Index

If on the Operation and Maintenance Stage's Date of Completion, the concessionaire has not obtained the PVTR, ANI will pay the Concessionaire the PVTR unearned balance following the formula specified in the contract on liquidation of the contract without the PVTR compliance.

The following PVTR values are established for the Autopista al Mar 2 Concession:

PVTR: USD \$ 231.95 million
PVTR8: USD \$ 66.92 million

PVTR13: USD \$ 120.82 million

PVTR18: USD \$ 168.69 million

\section{The project cash flow}

Income from the Concession Contract is projected monthly to prepare the project's cash flow, taking historical data as a reference. Also, the ADR established in the contract is discounted, and the monitoring of the $C D$ is established in years 8,13 , and 18 of the project. As a completely new project without historical information related to the annual traffic growth and its tariff structure, these values are projected with the assumptions established in section 3.b of the contract.

Three traffic scenarios are proposed to assess their impact on obtaining the Present Value of Toll Revenue PVTR.

- Base Scenario: As a base scenario, it was used the traffic study published by ANI in the data room of the process selection and granting process based on the expected projection; it was delivered through bidding process No. VJ-VE-APP-IPB-002-2015. The toll stations of Fuemia and Mutatá are entirely new, and there is no historical information. Projections are made for both tolls from the delivery date to come into operation, with Functional Unit 2 expected to be ready in 2020 . Figure 4 shows a projection of the expected daily vehicular traffic on the "Autopista al Mar 2" project.

Regarding toll rates, the information published on the website www.ani.gov.com on Fuemia and Mutatá tolls was used and, it was projected until 2040 with a per-year inflation rate at the end of each year. Table 6 shows the toll

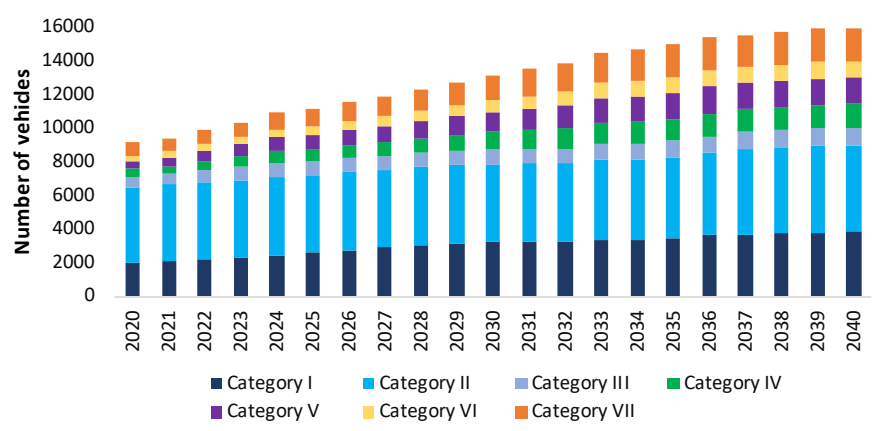

Figure 4: Projection of average daily traffic for the "Autopista al Mar 2" concession

Table 2: Tolls by category for the Autopista al Mar 2 project

\begin{tabular}{|c|c|c|}
\hline \multirow{2}{*}{ Type of vehicle } & \multicolumn{2}{|c|}{ Toll station (USD) } \\
\cline { 2 - 3 } & Fuemia & Mutatá \\
\hline Category I & 6.4 & 4.4 \\
\hline Category II & 7.9 & 5.5 \\
\hline Category III & 7.9 & 5.5 \\
\hline Category IV & 7.9 & 5.5 \\
\hline Category V & 18.9 & 13.1 \\
\hline Category VI & 23.7 & 16.5 \\
\hline Category VII & 27.4 & 19.0 \\
\hline
\end{tabular}




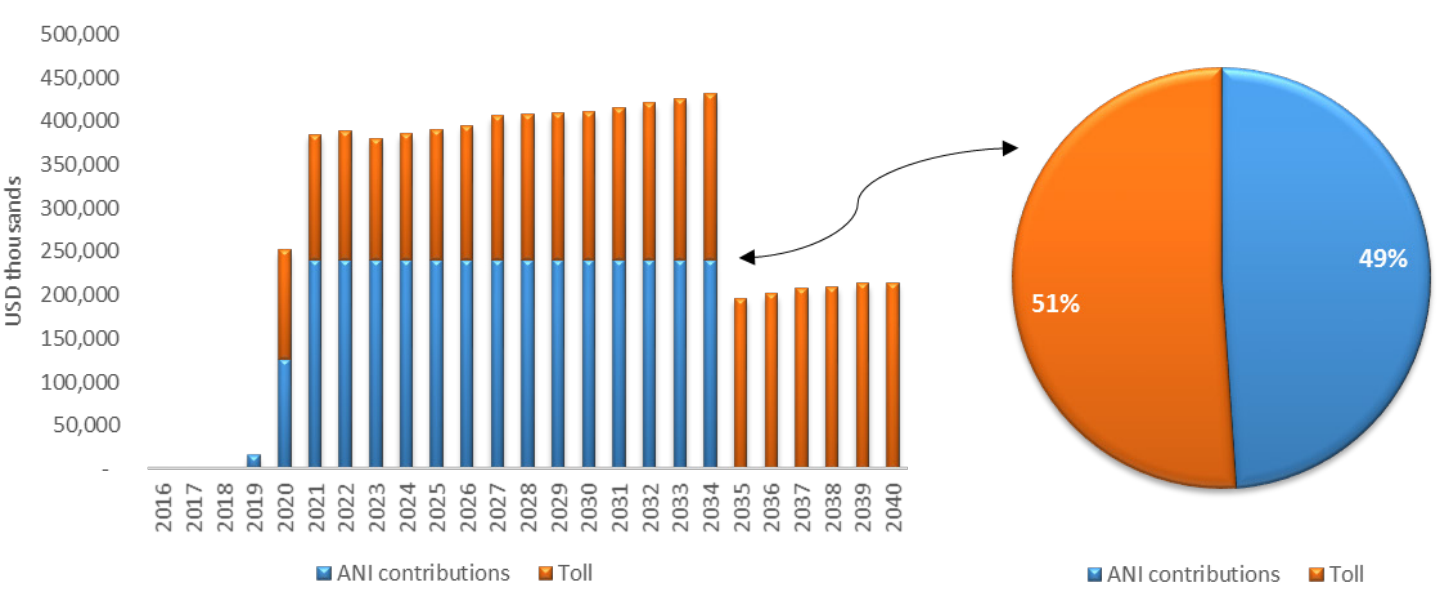

Figure 5: Base scenario income for "Autopista al Mar 2" concession

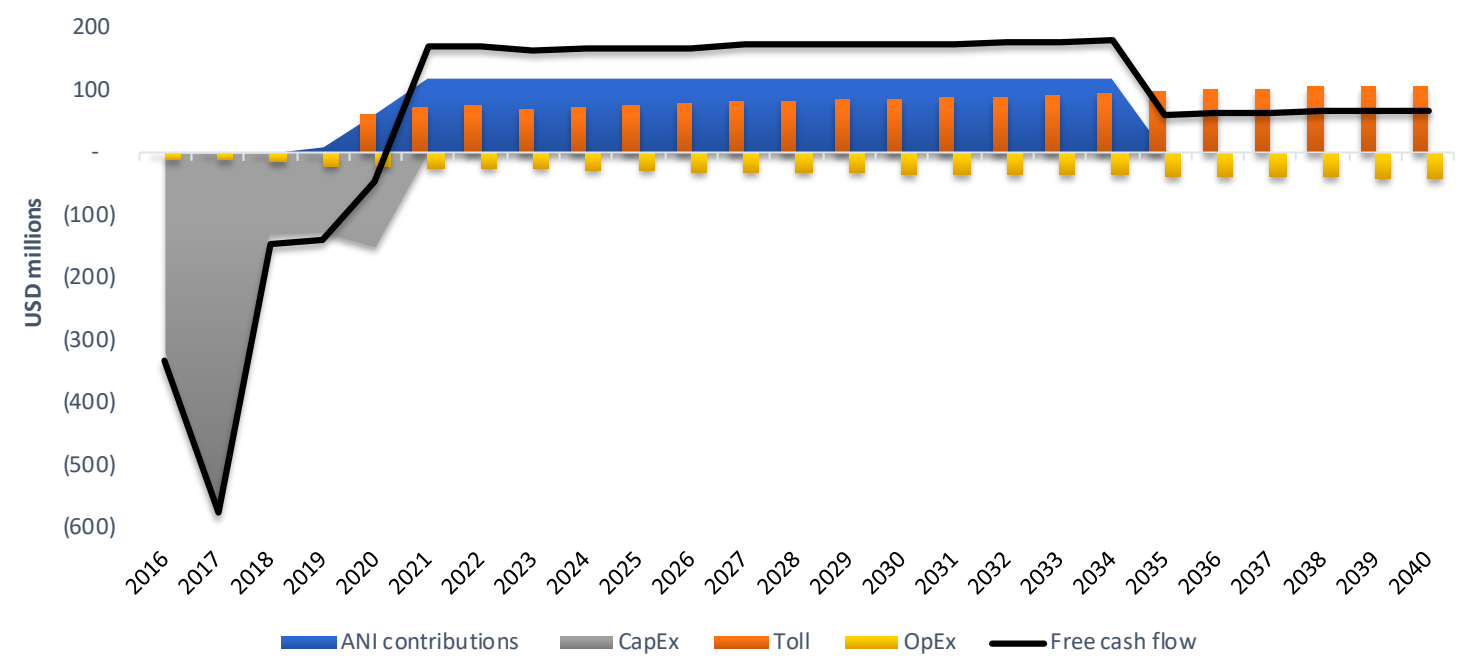

Figure 6: Autopista al Mar 2 Concession's base scenario Cash Flow

value for 2012 by type of vehicle established in section 4.2, "Rate structure of the special 4G concession contract".

- Pessimistic Scenario: A 30\% decrease in vehicle flow is simulated over the base scenario.

- Optimistic Scenario: A 30\% increase in vehicle flow is simulated over the base scenario.

An Excel model is developed based on the above information, using the macroeconomic projections reported by the Banco de la República; the Cash Flow calculation is made for the Autopista al Mar 2 project base scenario. Figure 5 shows project revenues from tolls and ANI contributions for the base scenario.

"Autopista al Mar 2" project cash flow is presented in Figure 6. With the proposed model, about $48 \%$ of the income corresponds to the State contributions invested in futures until 2034. In this type of infrastructure project, financing through Project Finance is ideal, given its high capital requirement at the beginning of the project.

PVTR denotes the present value in the reference month of toll collection, which ANI offered to the concessionaire. The model is developed for each proposed scenario to determine the PVTR in each reference year and determine the risks in each modeled scenario. The contract foresees the payment of a collection difference in favor of the concessionaire; ANI will pay it in cases where there is a negative difference between the present value of the project's actual money collection and the PVTR provided in the special part of the contract.

Collection differences (CD) will be calculated at three different times during the execution of each project: in years 8 (CD8), 13 (CD13), and 18 (CD18) and will be contrasted to the corresponding estimated PVTR defined in the special part of each contract. These resources will be deposited, if applicable, in each of these periods by ANI in the toll collection subaccount.

Table 3 presents the proposed base scenario model's results based on projected toll revenue data in the final concession contract. In this scenario, it is observed that the project's PVTR is reached well before the foreseen 25 years in the contract's structuring, and the commercial risk is not triggered by the collection differences in any of the years 8,13 , and 18 . This scenario generates an additional collection of \$ USD 123.18 million in present value in 2012, generating additional income for the concessionaire for operation and maintenance costs.

Table 4 presents the pessimistic scenario model's results, where the PVTR is not reached within the 25 years of the concession, and the risk of Collection Difference activates in year 18. Consequently, the amount of 
Table 3: Structuring of PVTR base scenario for the "Autopista al Mar 2" project

\begin{tabular}{|c|c|c|c|}
\hline Present Value from Toll Revenue & Estimate & Contractual & Additional revenue \\
\hline PVTR & 355.14 & 231.96 & 123.19 \\
\hline PVTR8 & 173.85 & 66.93 & 106.92 \\
\hline PVTR13 & 255.87 & 120.82 & 135.05 \\
\hline PVTR18 & 322.29 & 168.70 & 153.59 \\
\hline
\end{tabular}

Table 4: Structuring of PVTR pessimistic scenario for the Autopista al Mar 2 Project

\begin{tabular}{|c|c|c|c|}
\hline Present Value from Toll Revenue & Estimate & Contractual & Additional revenue \\
\hline PVTR & 184.67 & 231.96 & -47.28 \\
\hline PVTR8 & 90.40 & 66.93 & 23.48 \\
\hline PVTR13 & 133.05 & 120.82 & 12.23 \\
\hline PVTR18 & 167.59 & 168.70 & -1.11 \\
\hline
\end{tabular}

Table 5: Structuring of PVTR optimistic scenario for the Autopista al Mar 2 Project

\begin{tabular}{|c|c|c|c|}
\hline Present Value from Toll Revenue & Estimate & Contractual & Additional revenue \\
\hline PVTR & 887.86 & 231.96 & 655.90 \\
\hline PVTR8 & 434.63 & 66.93 & 367.70 \\
\hline PVTR13 & 639.67 & 120.82 & 518.85 \\
\hline PVTR18 & 805.73 & 168.70 & 637.03 \\
\hline
\end{tabular}

USD\$1.11 million in the present value placed in December 2012 must be paid to the concessionaire, initially, through the Contingency Fund provided by the State in the contract. If the surplus is covered with the Contingency Fund, ANI will transfer the remaining value to the concessionaire.

Table 5 presents the optimistic scenario model's results. In this scenario, the project's PVTR is reached before the foreseen eight years in the contract's structuring, and the commercial risk is not triggered by the collection differences in any of the years 8, 13, and 18. In this scenario, an additional collection of USD 655.9 million in present value was generated in 2012, producing additional income to the concessionaire for operating and maintenance costs.

\section{CONCLUSIONS}

Given that Colombia is a developing country, the constant search for mechanisms or alternative financing sources to meet the country's needs in terms of infrastructure becomes essential to improve productivity and increase economic development. So, the State becomes an active participant in infrastructure development, not only as an authority but also as a project planner and funder. Simultaneously, the establishment of Public-Private Partnerships makes the private sector, primarily the financial entities, a key player in infrastructure projects because of financial contribution, knowledge, and experience.

The Project Finance structure seeks to encourage the participation of the private sector in economic development through the construction of infrastructure, meeting efficiency expectations and technical capacity, and ef- fectiveness in financing matters. However, management issues related to profitability and risk make it hard to guarantee projects' viability. With the proposed Project Finance model, commercial risk assignment to the public mitigated financial imbalances. The Concessionaires have guaranteed income within the financing scheme by guaranteeing the income differential plus the State Contributions contemplated in the contract.

As observed, the project's traffic projection is a fundamental variable to achieve compliance with the PVTR in the 4G highway "Autopista al Mar 2". Considering that projects have a long-term structure, there is much uncertainty about the variables to incorporate in the model. In this sense, resorting to an income guarantee scheme mitigates the risk for the private against obtaining income, allowing banks or financers to have an additional guarantee for the repayment of their obligations and, therefore, to contribute to the financial closure of concession projects.

This study has significant implications for investors, the State, and public policymakers. From a managerial point of view, the State can significantly benefit from structuring the $4 G$ concessions projects via PPP and from financing through innovative mechanisms such as the PF. PF's use allows the achievement of high investment capital required in the short term of the project. To develop such an ambitious project as the $4 \mathrm{G}$ concessions requires large investments from the private sector both, national and foreign, to reduce the risk of these projects and, at the same time, to improve the use of the State's public resources. The findings imply that traffic projection is a relevant factor for financing the $4 G$ highways. This factor determines the project's income and the possibility 
of having financial imbalances. Also, a clear and precise financial evaluation since elaborating the contracts reduces the project's possible financial imbalances. Likewise, it will provide greater confidence and credibility for private investors to earn more significant economic benefits. Finally, both public and regulatory powers at national and international levels should create incentive programs (that is, subsidies) for companies that finance $4 G$ concessions. These policies will encourage other investors and other companies to invest in Colombia.

\section{REFERENCES}

1. González-Ruiz, J. D., Duque, E., \& Botero, S. (2017). The Process of Funding Highway Projects in Colombia: Outlook and Challenges. Institute of Transportation Engineers. ITE Journal, 87(8), 30.

2. González-Ruiz, Juan, Botero-Botero, S., \& Duque-Grisales, E. (2018). Financial Eco-Innovation as a Mechanism for Fostering the Development of Sustainable Infrastructure Systems. Sustainability, 10(12), 4463, DOI: 10.3390/su10124463.

3. Vassallo, J. M., Heras-Molina, J., Garrido, L., \& Gomez, J. (2020). Urban toll highway concession system in Santiago, Chile: Lessons learned after 15 years. Journal of Infrastructure Systems, 26(2), 05020004, DOI: 10.1061/(ASCE)IS.1943-555X.0000540

4. Clavijo, S., Vera, N., \& Cuellar, E. (2019). Financing Public Investment Through Concessions and Future Budgetary Obligations (FBO): The Case of Colombia 2002-2018. Available at SSRN: https://ssrn.com/abstract=3322690, DOI: 10.2139/ssrn.3322690

5. Peña, L. C., Miranda Velázquez, A., \& Gómez Torres, M. (2015). IDEAL 2014. La infraestructura en el desarrollo de América Latina. Infraestructura y cambio climático. Available at: https://scioteca.caf.com/ handle/123456789/748

6. Kogan, J., \& Bondorevsky, D. (2016). La infraestructura en el desarrollo de América Latina. Economía y Desarrollo, 156(1), 168-186. Available at: http://scielo.sld.cu/scielo.php?script=sci_arttext\&pid=S0252-85842016000100012\&Ing=es\&tl$\mathrm{ng}=\mathrm{en}$.

7. Engel, E. M., Fischer, R. D., \& Galetovic, A. (2010). The economics of infrastructure finance: Public-private partnerships versus public provision. EIB papers, 15(1), 40-69. Available at: http://hdl.handle. net/10419/45373

8. Engel, E., Fischer, R., \& Galetovic, A. (2013). The basic Public Finance of Public-Private Partnership. Journal of the European Economic Association, 11(1), 83-111. DOI: 10.1111/j.1542-4774.2012.01105.x
9. Jonas, A. E., Goetz, A. R., \& Brady, S. (2019). The global infrastructure public-private partnership and the extra-territorial politics of collective provision: The case of regional rail transit in Denver, USA. Urban Studies, 56(7), 1426-1447, DOI: 10.1177/0042098018811506

10. Cruz, C. O., \& Sarmento, J. M. (2018). The price of project finance loans for highways. Research in Transportation Economics, 70, 161-172, DOI: 10.1016/j.retrec.2017.09.006

11. Estrada, V. (2017). Estudio comparativo en la implementación de las Asociaciones Público-Privadas (APP). En Colombia, Perú, Brasil Y Argentina. Estudios Regionales. Asociación Ambiente y Sociedad.

12. Daube, D., Vollrath, S., \& Alfen, H. W. (2008). A comparison of Project Finance and the Forfeiting Model as financing forms for PPP projects in Germany. International Journal of Project Management, 26(4), 376-387, DOI: 10.1016/j.ijproman.2007.07.001

13. Grimsey, D., \& Lewis, M. K. (2002). Evaluating the risks of public private partnerships for infrastructure projects. International Journal of Project Management, 20(2), 107-118, DOI: 10.1016/S02637863(00)00040-5

14. Deng, Z., Song, S., \& Chen, Y. (2016). Private participation in infrastructure project and its impact on the project cost. China Economic Review, 39, 63-76, DOI: 10.1016/j.chieco.2016.04.004

15. Higuchi, T. (2019). Natural resource and PPP infrastructure projects and project finance. In Economics, Law, and Institutions in Asia Pacific. Springer, Singapore, DOI: 10.1007/978-981-13-2215-0

16. Biancone, P. P., \& Radwan, M. (2018). Sharia-Compliant financing for public utility infrastructure. Utilities Policy, 52, 88-94, DOI: 10.1016/j.jup.2018.03.006

17. Farquharson, E., Torres de Mästle, C., \& Yescombe, E. R. (2011). How to engage with the private sector in public-private partnerships in emerging markets. The World Bank, Washington DC.

18. Regan, M., Smith, J., \& Love, P. E. (2017). Financing of public private partnerships: Transactional evidence from Australian toll roads. Case Studies on Transport Policy, 5(2), 267-278, DOI: 10.1016/j. cstp.2017.01.003

19. Sarmento, J. M., \& Renneboog, L. (2016). Anatomy of public-private partnerships: Their creation, financing and renegotiations. International Journal of Managing Projects in Business, Vol. 9 No. 1, pp. 94-122, DOI: 10.1108/IJMPB-03-2015-0023 
20. González-Ruiz, JD, Duque, E., \& Restrepo, J. (2018). Clean Development Mechanism in Airports: The Colombian Case. In: Chau K., Chan I., Lu W., Webster C. (eds) Proceedings of the 21st International Symposium on Advancement of Construction Management and Real Estate. Springer, Singapore, DOI: 10.1007/978-981-10-6190-5_43

21. Jefferies, M., \& McGeorge, W. (2009). Using public-private partnerships (PPPs) to procure social infrastructure in Australia. Engineering, Construction and Architectural Management, Vol. 16 No. 5, pp. 415-437, DOI: 10.1108/09699980910988348

22. González, J. D., Rojas, M. D., Arboleda, C. A., \& Botero, S. (2014). Project Finance y Asociaciones Público-Privada para la provisión de servicios de infraestructura en Colombia. Obras y proyectos, 16, 61-82, DOI: 10.4067/S0718-28132014000200005

23. Lara-Galera, A. L., Sánchez-Soliño, A., \& Galindo-Aires, R. (2016). First generation highways. Participation loans valuation in the framework of real options. Journal of Construction, 15(2), 115-124, Available at: http://ojs.uc.cl/index.php/RDLC/article/view/12866

24. República de Colombia. (2012). Ley 1508 de 2012 , por la cual se establece el régimen jurídico de las Asociaciones Público Privadas. Available at: http:// www.suin-juriscol.gov.co/viewDocument.asp?ruta=Leyes $/ 1682473$

25. Gatti, S. (2013). Chapter 2-The Market for Project Finance: Applications and Sectors. En S. Gatti (Ed.), Project Finance in Theory and Practice (Second Edition) (pp. 27-42). Academic Press. http://www.sciencedirect.com/science/article/pii/ B9780123919465000025
26. Wibowo, A., \& Kochendörfer, B. (2005). Financial risk analysis of project finance in Indonesian toll roads. Journal of Construction Engineering and Management, 131(9), 963-972, DOI: 10.1061/(ASCE)07339364(2005)131:9(963)

27. Albújar, A. (2010). El Project Finance: Una técnica para viabilizar proyectos de infraestructura. Universidad ESAN - Documento de trabajo, 27.

28. Sainati, T., Locatelli, G., Smith, N., Brookes, N., \& Olver, G. (2020). Types and functions of special purpose vehicles in infrastructure megaprojects. International Journal of Project Management, 38(5), 243255, DOI: 10.1016/j.ijproman.2020.05.002

29. Akbıyıklı, R. (2013). Performance assessment of a private finance initiative road project. Transport, 28(1), 11-24, DOI: 10.3846/16484142.2013.778899

30. Borgonovo, E., Gatti, S., \& Peccati, L. (2010). What drives value creation in investment projects? An application of sensitivity analysis to project finance transactions. European Journal of Operational Research, 205(1), 227-236, DOI: 10.1016/j. ejor.2009.12.006

31. Yescombe, E. R. (2002). Chapter 3-The Project Finance Markets. En E. R. Yescombe (Ed.), Principles of Project Finance (pp. 21-32). Academic Press. http://www.sciencedirect.com/science/article/pii/ B9780127708515500038

32. Baker, S. H. (2011). Unimasking Project Finance: Risk mitigation, risk inducement and an invitation to development disaster? Texas Journal of Oil, Gas \& Energy Law, 6(2), 273-334. a9h. 